\title{
Vehicle Driver Warning Systems Using Road Marking and Traffic Light Detection
}

\author{
Akuwan Saleh ${ }^{l}$, Haryadi Amran D ${ }^{2}$, Amanda Septia A ${ }^{2}$ \\ ${ }^{1,2}$ (Department of Electrical Engineering, Politeknik Elektronika Negeri Surabaya, Surabaya, \\ Indonesia)
}

\begin{abstract}
Everyone has experienced fatigue and sleepiness while driving. This makes him not know the direction so that it violates traffic and can cause an accident. Violations that usually occur are breaking through traffic lights and violating road markings. Therefore, a simulation software was made to help negligent and sleepy drivers not to violate traffic and reduce accidents. The technology used is image processing with C\# programming and the EmguCV library using the Haar Cascade Classifier and Color Detection methods. Haarlike features are rectangular features, which give a specific indication of an image. The captured image will be processed in two stages, namely preprocessing to detect markings and Gaussian filter to detect traffic lights. The results of the preprocessing will be processed in the Haar Cascade Classifier to get the ROI of the marker and then look for the coordinates to find the distance between the marker and the driver. The limit used in measuring distance is $25.57 \mathrm{~cm}$ (85 pixels). If the coordinate distance is less than $25.57 \mathrm{~cm}$, the alarm will sound and alert the driver to stay away from the marker and if the coordinate distance is more than $25.57 \mathrm{~cm}$, the alarm will be off. While the results of the gaussian filter will be converted into HSV frames to detect red and green colors using the color pixel values of each color. The color of the light can be detected when the contour size value is between 0 and 6 .
\end{abstract}

KEYWORDS Road Marking, Image Processing, Haar Cascade Classifier, and Color Detection.

\section{INTRODUCTION}

Drowsiness is something that is always experienced by many people. If a person lacks sleep, is tired of working, and so on, it will definitely cause someone to be sleepy. Especially if someone is on the way. Especially in urban environments that require constant concentration of the driver resulting in visual fatigue [1]. Of course this is very detrimental because it can endanger yourself and others. Currently, there are frequent traffic violations that can lead to accidents. Most of the causes are due to negligent and sleepy drivers.

In the 2019 Land Transportation Statistics Data, During the 2015-2019 period, the number of traffic accidents has increased by an average of 4.87 percent per year. Improvement in the number of traffic accidents is followed by an increase in the number of dead and slightly injured by 1.41 percent and 6.26 percent, respectively. However, material losses increased by an average of 4.23 percent per year. Indonesian State Police (Korlantas POLRI) recorded the number of accidents in 2019 as many as 116,411 accidents. The number has incresed 6.59 percent compared to 2018 as many as 109,215 events [2].

Things like this must of course be minimized so that the number of violations can be reduced. To overcome these problems, in this research, the Detection of Road Marks and Traffic Lights Based on Image Processing is made. The detection is visualized in the form of software. If the driver approaches the road marking there will be a reminder alarm to notify the driver to stay away from the marking line, and if there is a traffic light, an alarm will sound to notify the driver if the light shows red or green.

With this detection can help drivers who are negligent or sleepy on the way so as to reduce traffic violations and avoid accidents.

\subsection{ROAD MARKINGS}

\section{MATERIAL AND METHOD}

Road marking is a sign located on the road surface or above the road surface which includes equipment or signs that form longitudinal lines, transverse lines, oblique lines and other symbols that function to direct traffic flow 
and limit traffic interest areas. Road markings are regulated in the Minister of Transportation Regulation Number 34 of 2014 [3].Longitudinal markings are marks that are parallel to the axis of the road. longitudinal markings connected by transverse lines used to delimit parking spaces in vehicle traffic lanes are not considered as longitudinal road markings. Types of road marks as shown Table 1.

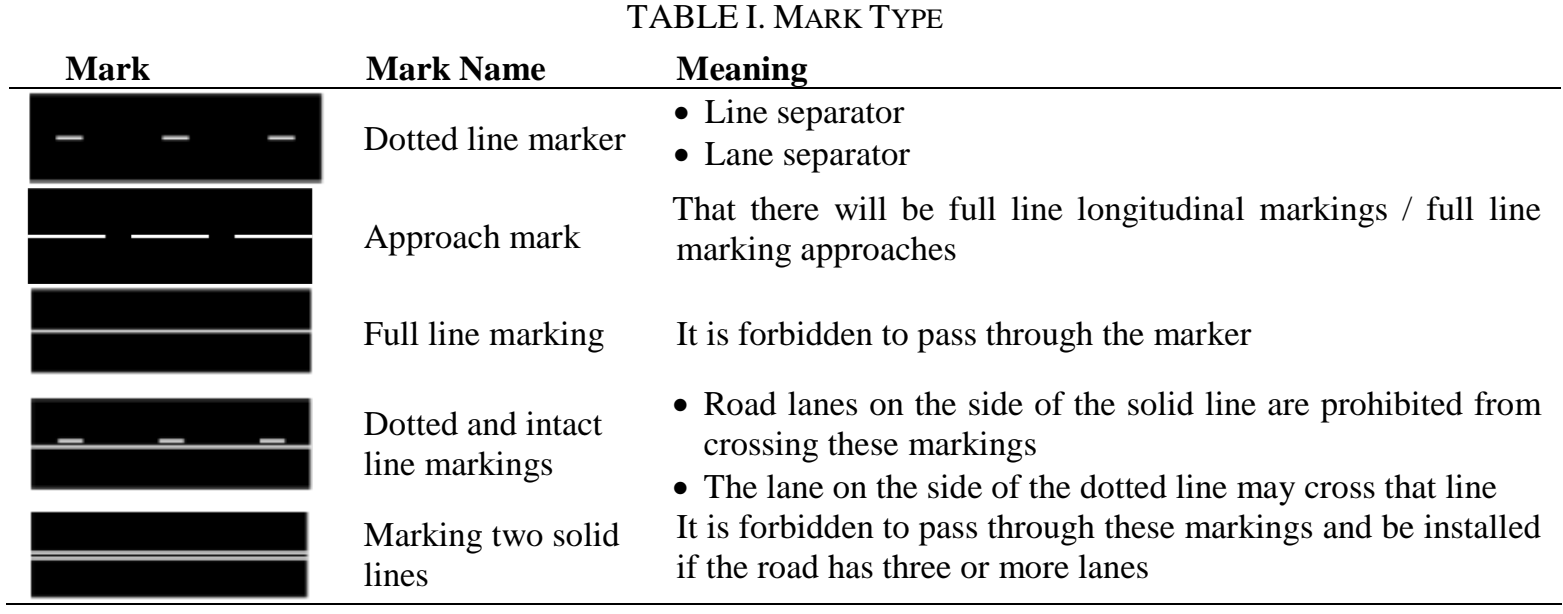

\subsection{Traffic Light}

Traffic lights (according to Law no. 22/2009 on Traffic andRoad Transportation: traffic signaling device or APILL) is a light that controls traffic flow installed at road junctions, zebra crossings, and other traffic flow areas. These lights indicate when the vehicle must run and stop alternately from various directions. Traffic regulation at crossroads is intended to regulate the movement of vehicles in each group of vehicle movements so that they can move alternately so that they do not interfere with each other between existing flows [4].

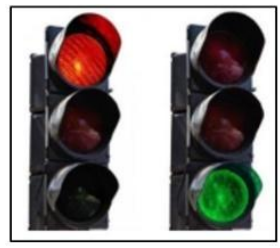

Fig.1. Example of traffic lights

\subsection{System PLANNING}

Software created using objects in the form of highways that have road markings and traffic lights. This object was recorded using a camera mounted on a motorcycle. Fig. 2 shows block diagrams and system flowcharts.

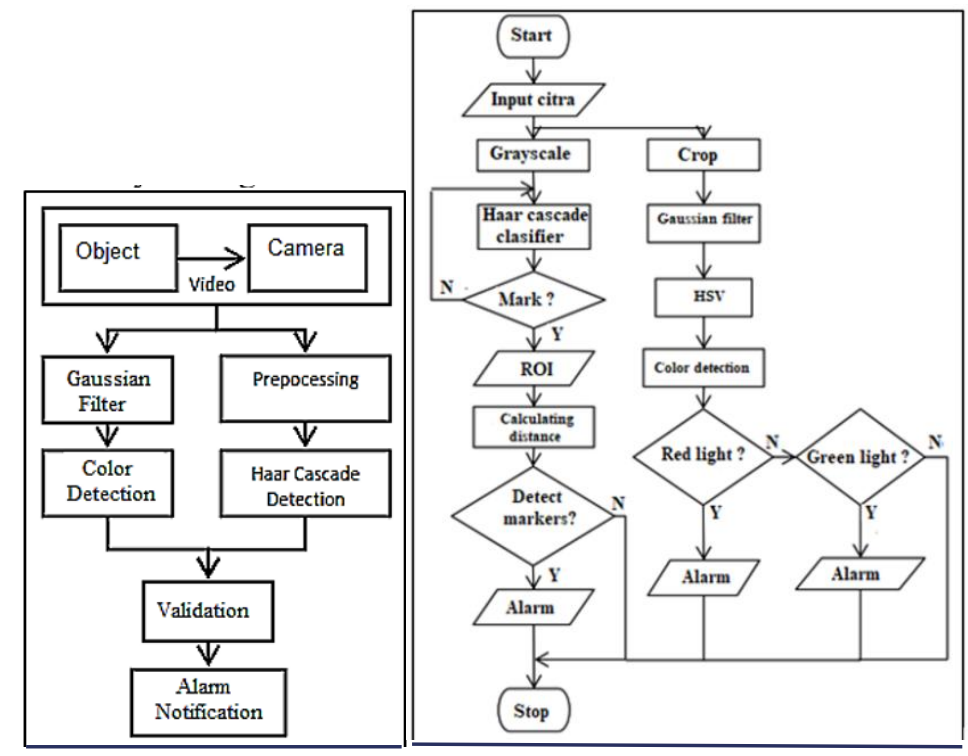

Fig. 2. Block diagrams and system flowcharts 
The videos obtained are processed by preprocessing and followed by the haar cascade classifier for get the road marking object. Meanwhile, to detect traffic lights, video frames will be cropped and processed with a gaussian filter and followed by color detection to detect the color of traffic lights. If the traffic light is red, the alarm will activate and warn the driver to stop, if the light is green, the alarm will tell you to keep going, if the driver approaches the marker, the alarm will warn you to stay away from the marker.For more details,

\subsection{GAUSSIAN FILTER}

Gaussian filter or gaussian blur filter is one of the basic and widely used image processing techniques. Gaussian filter [5] is a basic preprocessor used to remove noise in each image, then the image is transferred to a gray map. Gaussian filters are very good at removing normally distributed noise. In Figure 3, after converting the image to grayscale, cropping is done and the next step is to determine the mask. Masks that are often used for image improvement are Gaussian smoothing masks [6],[7]. The weights on the Gaussian smoothing mask follow a normal distribution as stated in the equation below:

Where:

$$
h(m, n)=\frac{1}{2 \pi \sigma^{2}} e^{\frac{-\left(m^{2}+n^{2}\right)}{2 \sigma^{2}}}
$$

- $\sigma$ is the standard deviation value of the normal distribution used. The greater the value of $\sigma$, the more neighboring points are included in the calculation.

- $\quad x=m$ and $y=n$ are the coordinates of the mask where the coordinates $(0,0)$ are the positions of the midpoint of the mask that have the greatest / highest value.

- $\pi$ is a constant with the value 3.14 .

- $\quad \mathrm{e}$ is a natural number constant with the value 2.718281828

\section{5 haAr Cascade Classifier}

The haar cascade method uses the haar feature function which requires prior training to obtain a decision tree called the cascade classifier, to determine the presence or absence of objects in the processed image [8]. In general, Haar-Like Feature is used to detect objects in digital images [9]. The haar cascade classifier method is used to detect road markings. Where this method will classify marker data existing ones to find suitable features. The vehicle camera captures RGB three-channel color images, and most of the road markings are white [10].The first thing to do is change the RGB frame to a grayscale frame. This frame each pixel has a gradient color ranging from white to black (0-255). Then the results of this frame are processed using the haar cascade classifier method. Fig.3shows the flowchart and process of the haar cascade classifier for road marking detection.

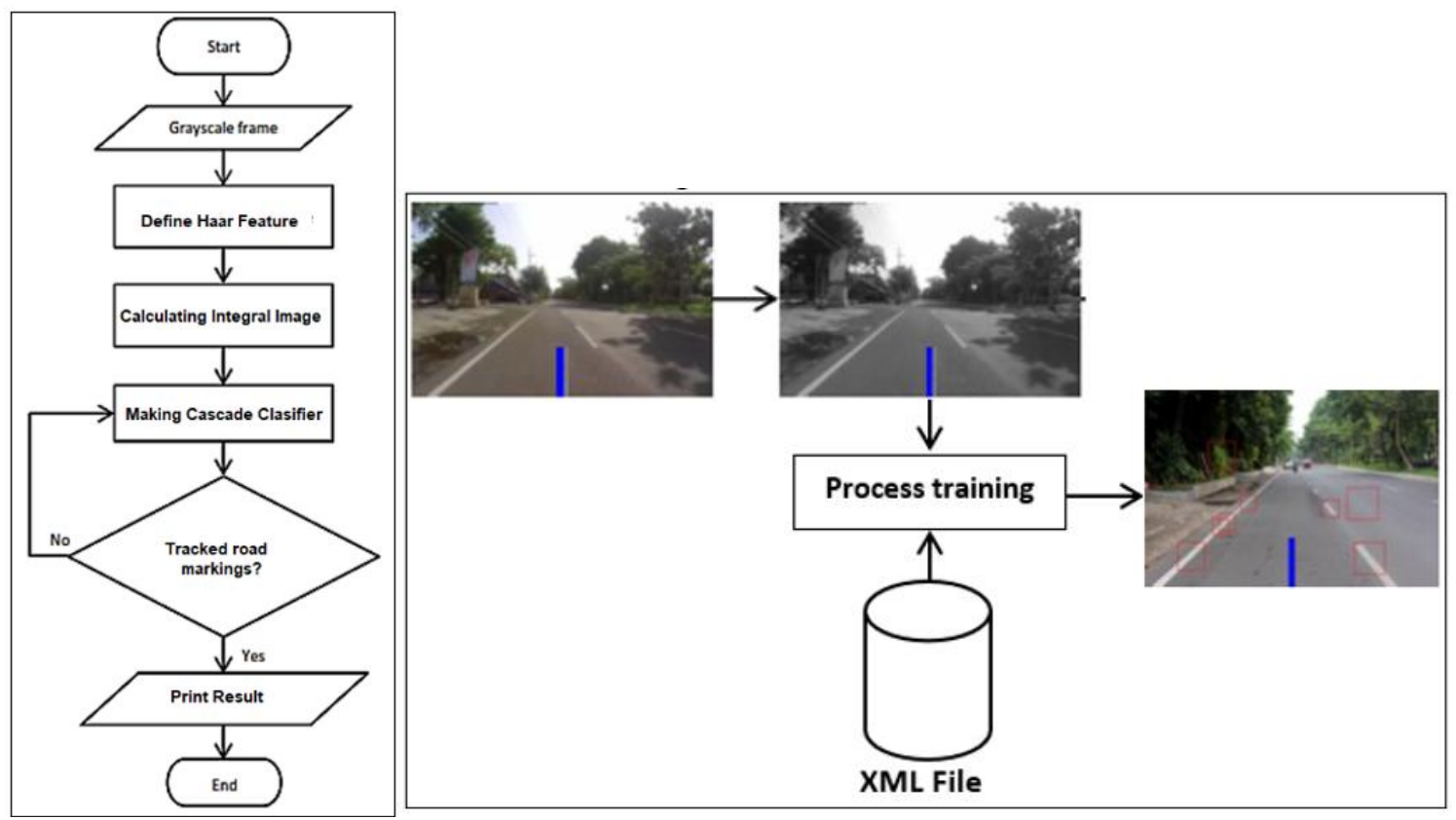

Fig.3. Flowchart and process of haar cascade classifier

This method will classify existing road marking data to find features that match the road markings and this feature is used to detect road markings.In haar cascade classifier must first create an XML file first. First of 
all, make a positive and negative picture. Positive images are images of road markings, while negative images are images other than road markings. Then make a positive data sample by cropping the images one by one. Positive data samples are stored in vector files. The next process is doing training. This process is carried out to obtain features that match the road markings. The more features that are used, the longer it takes to classify. The pre-built cascade classifiers are combined or converted into an XML file. This file will be read or loaded on the program so that it can detect traffic signs and lights. Region of interest (ROI) detector helps prune the image to portions which are good candidates for being road markings [11].To determine the distance, the distance between the coordinates of the ROI marker with red box line and the driver's coordinates (blue line) is used. The formula used to determine the distance is as follows:

$$
\begin{gathered}
(x, \mathrm{y})=x+\frac{\text { width }}{2}, y+\frac{\text { height }}{2} \\
\text { distance }(\text { pixels })=\sqrt{(\mathrm{x} 2-\mathrm{x} 1)^{2}+(\mathrm{y} 2-\mathrm{y} 1)^{2}} \\
\text { distance }(\mathrm{cm})=\text { pixel value } \mathrm{x} 0.300808422
\end{gathered}
$$

The distance of the resulting marker is from the coordinates of the marker and the driver who then calibrated with 0.300808422 this value is the pixel/cm value.

\subsection{COLOR DETECTION}

In detecting traffic lights, color detection is used. Where the colors to be detected are red and green. The method takescropped RGB color images as the input. Images are then converted from the RGB color space to the HSV color space [12]. Frames that have been cropped and filtered using a Gaussian filter are converted to HSV and then red and green are searched for using the minimum and maximum values for each color.

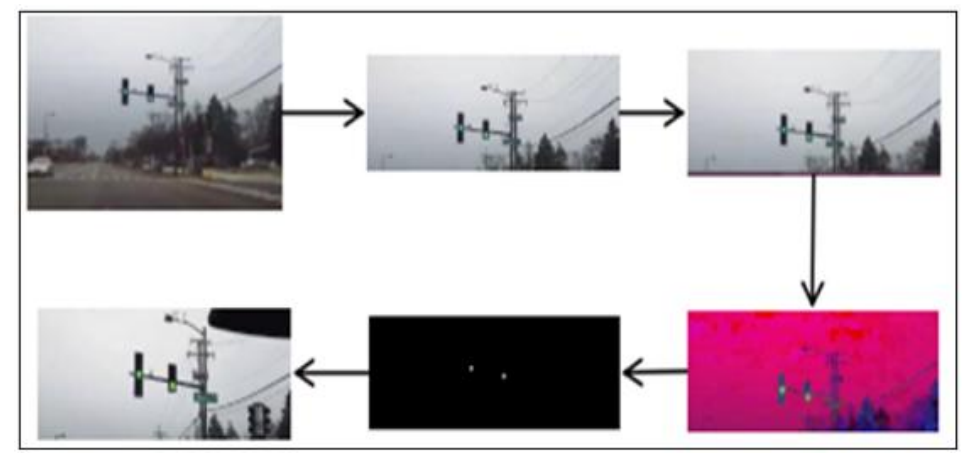

Fig.5. Color detection process

Where the value of red has a minimum value $(166,84,141)$ and maximum $(186,255,255)$ while the green color has a minimum value $(66,122,129)$ and a maximum $(86,255,255)$. To get the ROI of the lamp, contour is used. If the contour size has a value between 0 to 6 , then the ROI of the lamp will appear, if the contour size value is other than 0 to 6 then the ROI does not appear.

\section{RESULT AND DISCUSSION}

System testing is carried out based on light intensity, namely in light, overcast, and dark conditions. In testing road markings, three road locations were used.The first video takes the Dr.Ir.H.Soekarno road near campus C UNAIR, the second video takes the southern Dr.Ir.H.Soekarno road, and the third video takes the Kertajaya Indah road in the city of Surabaya, Indonesia.Traffic light testing was carried out from Jalan Ijen to Jalan Kawi in the Malang City area, Indonesia. The time needed in bright conditions to get results in the form of information about road markings and traffic lights that are detected is 1.6 seconds. Meanwhile, when it is overcast and dark, the time it takes is 0.9 seconds.

\subsection{ROAD MARK DETECTION}

Table 2. is the result of testing which shows that video 1 , video 2 , and video 3 can detect road markings in light, overcast, and dark conditions. This is indicated by the appearance of a red ROI rectangle on the frame. 
TABLE 2. ROAD MARK DETECTION RESULTS

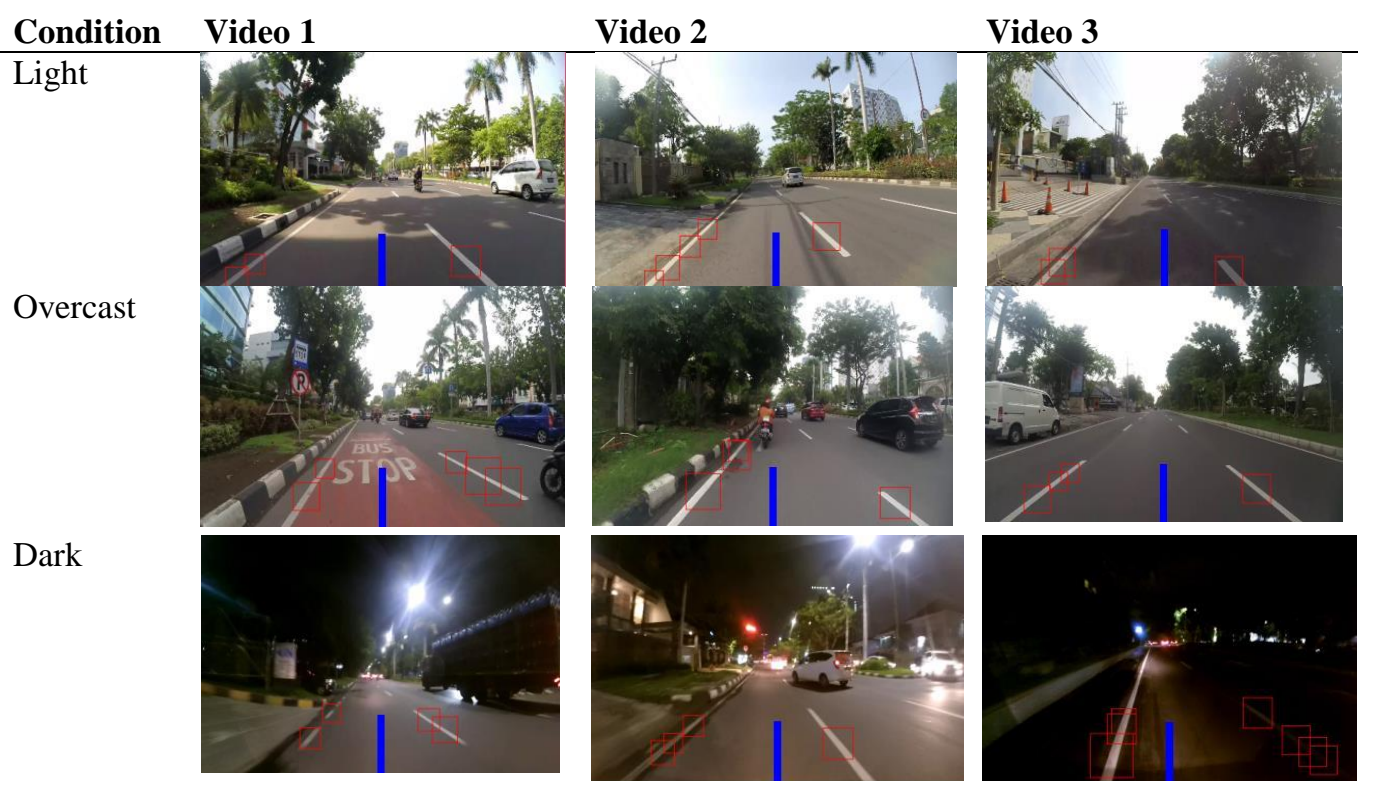

Tables 3 to 11 are test results data on road markings consisting of contour values, coordinate values, distances in pixels, distances in centimeters, voice, and descriptions.

3.1.1 DETECTION OF ROAD MARKINGS IN LIGHT CONDITIONS

The test results on video 1, video 2, and video 3 in light conditions are shown in Tables 3 to 5 .

TABLE 3. TEST RESULT ON VIDEO 1

\begin{tabular}{llllllll}
\hline $\begin{array}{l}\text { Seconds } \\
\text { to }\end{array}$ & Contour Value & \multicolumn{2}{c}{ Value $(\mathbf{x , y})$} & $\begin{array}{c}\text { Distance } \\
\text { (pixels) }\end{array}$ & $\begin{array}{c}\text { Distance } \\
(\mathbf{c m})\end{array}$ & $\begin{array}{c}\text { Voi } \\
\text { ce }\end{array}$ & Description \\
\hline 10 & $\mathrm{X}=268, \mathrm{Y}=241, \mathrm{~W}=43, \mathrm{H}=43$ & 289 & 262 & 46.329 & 13.9349 & On & Stay away from Marks \\
20 & $\mathrm{X}=284, \mathrm{Y}=260, \mathrm{~W}=48, \mathrm{H}=48$ & 308 & 284 & 47.1699 & 14.1891 & On & Stay away from Marks \\
30 & $\mathrm{X}=134, \mathrm{Y}=238, \mathrm{~W}=43, \mathrm{H}=43$ & 155 & 259 & 116.811 & 35.1377 & Off & Safe Distance \\
40 & $\mathrm{X}=296, \mathrm{Y}=154, \mathrm{~W}=27, \mathrm{H}=27$ & 309 & 167 & 141.354 & 42.5204 & Off & Safe Distance \\
50 & $\mathrm{X}=346, \mathrm{Y}=207, \mathrm{~W}=51, \mathrm{H}=51$ & 371 & 232 & 127.318 & 38.2983 & Off & Safe Distance \\
60 & $\mathrm{X}=174, \mathrm{Y}=230, \mathrm{~W}=67, \mathrm{H}=67$ & 207 & 263 & 68.5054 & 20.6070 & On & Stay away from Marks \\
\hline
\end{tabular}

TABLE 4. TEST RESULT ON VIDEO 2

\begin{tabular}{llllllll}
\hline $\begin{array}{l}\text { Seconds } \\
\text { to }\end{array}$ & \multicolumn{1}{c}{ Contour Value } & \multicolumn{2}{c}{ Value $(\mathbf{x , y})$} & $\begin{array}{c}\text { Distance } \\
\text { (pixels) }\end{array}$ & $\begin{array}{c}\text { Distance } \\
(\mathbf{c m})\end{array}$ & $\begin{array}{l}\text { Voi } \\
\text { ce }\end{array}$ & Description \\
\hline 10 & $\mathrm{X}=286, \mathrm{Y}=258, \mathrm{~W}=43, \mathrm{H}=43$ & 307 & 279 & 48.3011 & 14.5293 & On & Stay away from Marks \\
20 & $\mathrm{X}=242, \mathrm{Y}=279, \mathrm{~W}=30, \mathrm{H}=30$ & 257 & 294 & 9.8994 & 2.97782 & On & Stay away from Marks \\
30 & $\mathrm{X}=437, \mathrm{Y}=122, \mathrm{~W}=40, \mathrm{H}=40$ & 457 & 142 & 250.059 & 75.2198 & Off & Safe Distance \\
40 & $\mathrm{X}=36, \mathrm{Y}=288, \mathrm{~W}=26, \mathrm{H}=26$ & 49 & 301 & 215 & 64.6738 & Off & Safe Distance \\
50 & $\mathrm{X}=171, \mathrm{Y}=246, \mathrm{~W}=58, \mathrm{H}=58$ & 200 & 275 & 69.0796 & 20.7797 & On & Stay away from Marks \\
60 & $\mathrm{X}=338, \mathrm{Y}=243, \mathrm{~W}=46, \mathrm{H}=46$ & 361 & 266 & 103.121 & 21.0196 & Off & Safe Distance \\
\hline
\end{tabular}

TABLE 5. TEST RESULTS ON VIDEO 3

\begin{tabular}{|c|c|c|c|c|c|c|c|}
\hline \multirow{2}{*}{$\begin{array}{l}\text { Seconds } \\
\text { to }\end{array}$} & \multirow[t]{2}{*}{ Contour Value } & \multicolumn{2}{|c|}{ Value $(x, y)$} & \multirow{2}{*}{$\begin{array}{c}\text { Distance } \\
\text { (pixels) }\end{array}$} & \multirow{2}{*}{$\begin{array}{c}\text { Distance } \\
(\mathbf{c m})\end{array}$} & \multirow{2}{*}{$\begin{array}{l}\text { Voi } \\
\text { ce }\end{array}$} & \multirow[t]{2}{*}{ Description } \\
\hline & & $\mathbf{X}$ & $\mathbf{Y}$ & & & & \\
\hline 10 & $X=107, Y=263, W=31, H=31$ & 122 & 278 & 143.850 & 43.2712 & Off & Safe Distance \\
\hline 20 & $\mathrm{X}=299, \mathrm{Y}=129, \mathrm{~W}=44, \mathrm{H}=44$ & 321 & 151 & 160.464 & 48.2689 & Off & Safe Distance \\
\hline 30 & $X=254, Y=223, W=76, H=76$ & 292 & 261 & 48.8262 & 14.6873 & On & Stay away from Marks \\
\hline 40 & $\mathrm{X}=394, \mathrm{Y}=267, \mathrm{~W}=34, \mathrm{H}=34$ & 411 & 284 & 147.979 & 44.5135 & Off & Safe Distance \\
\hline 50 & $\mathrm{X}=288, \mathrm{Y}=253, \mathrm{~W}=42, \mathrm{H}=42$ & 309 & 274 & 52.4785 & 15.7859 & On & Stay away from Marks \\
\hline 60 & $X=336, Y=213, W=45, H=45$ & 358 & 235 & 114.856 & 34.5496 & Off & Safe Distance \\
\hline
\end{tabular}

$\mathrm{W}=$ Width, $\mathrm{H}=$ Height 
From the data generated, in Table 3 it can be seen that the driver approaches the road markings at the 10th, 20th, and 60th seconds so that the alarm is on.For Table 4 the driver approaches the road markings at the 10th, 20th, 50th seconds. While in Table 5, the driver approaches the road markings at the 30th and 50th seconds.Based on the 10th second data in table 5, the ROI coordinate value can be calculated using equation 2:

$$
(x, y)=\left(107+\frac{31}{2}\right),\left(263+\frac{31}{2}\right)=(122.5,278.5)
$$

Furthermore, the calculation of distance (pixels) and distance $(\mathrm{cm})$ can be calculated by equations 3 and 4 .

$$
\begin{aligned}
& \text { distance }(\text { pixels })=\sqrt{(264-122)^{2}+(301-278)^{2}}=\sqrt{20693}=143.850 \\
& \text { distance }(\mathrm{cm})=143.850 \times 0.300808422=43.2712
\end{aligned}
$$

\subsubsection{DETECTION OF ROAD MARKINGS IN OVERCAST CONDITIONS}

The test results on Tables 6 to 8 are the results of tests on video 1, video 2, and video 3 which were carried out in cloudy/overcast conditions.

TABLE 6. TEST RESULTS ON VIDEO 1

\begin{tabular}{|c|c|c|c|c|c|c|c|}
\hline \multirow{2}{*}{$\begin{array}{l}\text { Seconds } \\
\text { to }\end{array}$} & \multirow[t]{2}{*}{ Contour Value } & \multicolumn{2}{|c|}{ Value $(\mathbf{x}, \mathbf{y})$} & \multirow{2}{*}{$\begin{array}{c}\text { Distance } \\
\text { (pixels) }\end{array}$} & \multirow{2}{*}{$\begin{array}{c}\text { Distance } \\
\text { (cm) }\end{array}$} & \multirow{2}{*}{$\begin{array}{l}\text { Voi } \\
\text { ce }\end{array}$} & \multirow[t]{2}{*}{ Description } \\
\hline & & $\mathbf{X}$ & $\mathbf{Y}$ & & & & \\
\hline 10 & $X=317, Y=220, W=37, H=37$ & 335 & 238 & 94.9210 & 28.5530 & Off & Safe Distance \\
\hline 20 & $\mathrm{X}=221, \mathrm{Y}=243, \mathrm{~W}=44, \mathrm{H}=44$ & 243 & 265 & 41.6773 & 12.5368 & On & Stay away from Marks \\
\hline 30 & $X=266, Y=251, W=50, H=50$ & 291 & 276 & 36.7967 & 11.0687 & On & Stay away from Marks \\
\hline 40 & $X=280, Y=256, W=40, H=40$ & 300 & 276 & 44.8292 & 13.4850 & On & Stay away from Marks \\
\hline 50 & $X=261, Y=196, W=35, H=35$ & 278 & 213 & 89.1066 & 26.8040 & Off & Safe Distance \\
\hline 60 & $X=174, Y=260, W=50, H=50$ & 199 & 285 & 66.9402 & 20.1361 & On & Stay away from Marks \\
\hline
\end{tabular}

\begin{tabular}{llllllll}
\hline $\begin{array}{l}\text { Seconds } \\
\text { to }\end{array}$ & Contour Value & \multicolumn{2}{c}{ Value $(\mathbf{x , y})$} & $\begin{array}{c}\text { Distance } \\
\text { (pixels) }\end{array}$ & $\begin{array}{c}\text { Distance } \\
(\mathbf{c m})\end{array}$ & $\begin{array}{c}\text { Voi } \\
\text { ce }\end{array}$ & Description \\
\hline 10 & $\mathrm{X}=93, \mathrm{Y}=276, \mathrm{~W}=35, \mathrm{H}=35$ & 110 & 293 & 154.207 & 46.3867 & Off & Safe Distance \\
20 & $\mathrm{X}=164, \mathrm{Y}=205, \mathrm{~W}=25, \mathrm{H}=25$ & 176 & 217 & 121.655 & 36.5948 & Off & Safe Distance \\
30 & $\mathrm{X}=253, \mathrm{Y}=205, \mathrm{~W}=32, \mathrm{H}=32$ & 269 & 221 & 80.1560 & 24.1115 & On & Stay away from Marks \\
40 & $\mathrm{X}=182, \mathrm{Y}=243, \mathrm{~W}=38, \mathrm{H}=38$ & 201 & 262 & 74.0945 & 22.2882 & On & Stay away from Marks \\
50 & $\mathrm{X}=170, \mathrm{Y}=236, \mathrm{~W}=31, \mathrm{H}=31$ & 185 & 251 & 93.4933 & 28.1235 & Off & Safe Distance \\
60 & $\mathrm{X}=341, \mathrm{Y}=238, \mathrm{~W}=40, \mathrm{H}=40$ & 361 & 258 & 106.103 & 31.9166 & Off & Safe Distance \\
\hline
\end{tabular}

TABLE 7. TEST RESULTS ON VIDEO 2

\begin{tabular}{|c|c|c|c|c|c|c|c|}
\hline \multirow{2}{*}{$\begin{array}{l}\text { Seconds } \\
\text { to }\end{array}$} & \multirow[t]{2}{*}{ Contour Value } & \multicolumn{2}{|c|}{ Value $(x, y)$} & \multirow{2}{*}{$\begin{array}{c}\text { Distance } \\
\text { (pixels) }\end{array}$} & \multirow{2}{*}{$\begin{array}{c}\text { Distance } \\
\text { (cm) }\end{array}$} & \multirow{2}{*}{$\begin{array}{l}\text { Voi } \\
\text { ce }\end{array}$} & \multirow[t]{2}{*}{ Description } \\
\hline & & $\mathbf{X}$ & $\mathbf{Y}$ & & & & \\
\hline 10 & $\mathrm{X}=376, \mathrm{Y}=262, \mathrm{~W}=41, \mathrm{H}=41$ & 396 & 282 & 133.360 & 40.1158 & Off & Safe Distance \\
\hline 20 & $\mathrm{X}=237, \mathrm{Y}=258, \mathrm{~W}=34, \mathrm{H}=34$ & 254 & 275 & 27.8567 & 8.37952 & On & Stay away from Marks \\
\hline 30 & $\mathrm{X}=366, \mathrm{Y}=258, \mathrm{~W}=32, \mathrm{H}=32$ & 382 & 274 & 121.049 & 36.4125 & Off & Safe Distance \\
\hline 40 & $X=168, Y=248, W=53, H=53$ & 194 & 274 & 75.0266 & 24.5686 & On & Stay away from Marks \\
\hline 50 & $\mathrm{X}=331, \mathrm{Y}=249, \mathrm{~W}=39, \mathrm{H}=39$ & 350 & 268 & 92.1140 & 27.7086 & Off & Safe Distance \\
\hline 60 & $\mathrm{X}=362, \mathrm{Y}=282, \mathrm{~W}=31, \mathrm{H}=31$ & 377 & 297 & 113.070 & 34.1240 & Off & Safe Distance \\
\hline
\end{tabular}

TABLE 8. TEST RESULTS ON VIDEO 3

$\mathrm{W}=$ Width, $\mathrm{H}=$ Height

Based on the 10th second data in table 8 , the ROI coordinate value can be calculated using equation 2:

$$
(x, y)=(369.5,282.5)
$$

$$
(x, y)=\left(376+\frac{41}{2}\right),\left(262+\frac{41}{2}\right)
$$

Furthermore, the calculation of distance (pixels) and distance $(\mathrm{cm})$ can be calculated by equations 3 and 4 .

$$
\begin{gathered}
\text { distance }(\text { pixels })=\sqrt{(264-369)^{2}+(301-282)^{2}}=\sqrt{17785}=133.360 \\
\operatorname{distance}(\mathrm{cm})=133.360 \times 0.300808422=40.1158
\end{gathered}
$$

\subsubsection{DETECTION OF ROAD MARKINGS IN DARK CONDITIONS}

The test results on Tables 9 to 11 are the results of tests on video 1, video 2, and video 3 which were carried out in dark conditions. 
TABLE 9. TEST RESULTS ON VIDEO 1

\begin{tabular}{llllllll}
\hline $\begin{array}{l}\text { Seconds } \\
\text { to }\end{array}$ & Contour Value & \multicolumn{2}{c}{ Value $(\mathbf{x , y})$} & $\begin{array}{c}\text { Distance } \\
\text { (pixels) }\end{array}$ & $\begin{array}{c}\text { Distance } \\
(\mathbf{c m})\end{array}$ & $\begin{array}{c}\text { Voi } \\
\text { ce }\end{array}$ & Description \\
\hline 10 & $\mathrm{X}=223, \mathrm{Y}=251, \mathrm{~W}=54, \mathrm{H}=54$ & 250 & 278 & 26.9258 & 8.09950 & On & Stay away from Marks \\
20 & $\mathrm{X}=265, \mathrm{Y}=280, \mathrm{~W}=33, \mathrm{H}=33$ & 381 & 296 & 117.106 & 35.2264 & Off & Safe Distance \\
30 & $\mathrm{X}=390, \mathrm{Y}=290, \mathrm{~W}=27, \mathrm{H}=27$ & 403 & 303 & 139.012 & 41.8159 & Off & Safe Distance \\
40 & $\mathrm{X}=276, \mathrm{Y}=261, \mathrm{~W}=44, \mathrm{H}=44$ & 298 & 283 & 38.4707 & 11.5723 & On & Stay away from Marks \\
50 & $\mathrm{X}=171, \mathrm{Y}=217, \mathrm{~W}=25, \mathrm{H}=25$ & 183 & 229 & 108.374 & 32.7802 & Off & Safe Distance \\
60 & $\mathrm{X}=320, \mathrm{Y}=224, \mathrm{~W}=30, \mathrm{H}=30$ & 335 & 239 & 94.2602 & 28.3542 & Off & Safe Distance \\
\hline
\end{tabular}

TABLE 10. TEST RESULTS ON VIDEO 2

\begin{tabular}{|c|c|c|c|c|c|c|c|}
\hline \multirow{2}{*}{$\begin{array}{l}\text { Seconds } \\
\text { to }\end{array}$} & \multirow[t]{2}{*}{ Contour Value } & \multicolumn{2}{|c|}{ Value $(x, y)$} & \multirow{2}{*}{$\begin{array}{c}\text { Distance } \\
\text { (pixels) }\end{array}$} & \multirow{2}{*}{$\begin{array}{c}\text { Distance } \\
(\mathbf{c m})\end{array}$} & \multirow{2}{*}{$\begin{array}{l}\text { Voi } \\
\text { ce }\end{array}$} & \multirow[t]{2}{*}{ Description } \\
\hline & & $\mathbf{X}$ & $\mathbf{Y}$ & & & & \\
\hline 10 & $\mathrm{X}=328, \mathrm{Y}=251, \mathrm{~W}=37, \mathrm{H}=37$ & 346 & 269 & 88.0222 & 26.4778 & Off & Safe Distance \\
\hline 20 & $X=335, Y=247, W=44, H=44$ & 357 & 269 & 98.3514 & 29.5849 & Off & Safe Distance \\
\hline 30 & $X=291, Y=224, W=46, H=46$ & 314 & 247 & 73.5934 & 22.1375 & On & Stay away from Marks \\
\hline 40 & $X=150, Y=216, W=32, H=32$ & 166 & 232 & 119.854 & 36.0530 & Off & Safe Distance \\
\hline 50 & $X=129, Y=264, W=33, H=33$ & 145 & 280 & 120.838 & 36.3490 & Off & Safe Distance \\
\hline 60 & $X=228, Y=230, W=65, H=65$ & 260 & 262 & 39.2045 & 11.7930 & On & Stay away from Marks \\
\hline
\end{tabular}

TABLE 11. TEST RESULTS ON VIDEO 3

\begin{tabular}{llllllll}
\hline Seconds to & \multicolumn{1}{c}{ Contour Value } & \multicolumn{2}{c}{ Value $(\mathbf{x , y})$} & $\begin{array}{c}\text { Distance } \\
\text { (pixels) }\end{array}$ & $\begin{array}{c}\text { Distance } \\
(\mathbf{c m})\end{array}$ & $\begin{array}{c}\text { Voi } \\
\text { ce }\end{array}$ & \multicolumn{1}{c}{ Description } \\
& & $\mathbf{X}$ & $\mathbf{Y}$ & $\mathrm{n}$ & & \\
\hline 10 & $\mathrm{X}=242, \mathrm{Y}=246, \mathrm{~W}=48, \mathrm{H}=48$ & 266 & 270 & 31.0644 & 9.34443 & On & Stay away from Marks \\
20 & $\mathrm{X}=271, \mathrm{Y}=208, \mathrm{~W}=45, \mathrm{H}=45$ & 293 & 230 & 76.6941 & 23.0702 & On & Stay away from Marks \\
30 & $\mathrm{X}=151, \mathrm{Y}=249, \mathrm{~W}=43, \mathrm{H}=43$ & 172 & 270 & 97.8243 & 29.4263 & Off & Safe Distance \\
40 & $\mathrm{X}=94, \mathrm{Y}=250, \mathrm{~W}=48, \mathrm{H}=48$ & 118 & 274 & 148.475 & 44.6625 & Off & Safe Distance \\
50 & $\mathrm{X}=211, \mathrm{Y}=229, \mathrm{~W}=47, \mathrm{H}=47$ & 234 & 252 & 57.4543 & 17.2827 & On & Stay away from Marks \\
60 & $\mathrm{X}=372, \mathrm{Y}=229, \mathrm{~W}=52, \mathrm{H}=52$ & 398 & 255 & 141.675 & 42.6170 & Off & Safe Distance \\
\hline
\end{tabular}

$\mathrm{W}=$ Width, $\mathrm{H}=$ Height

The $\mathrm{x}$ and $\mathrm{y}$ coordinate values or can be called the midpoint are obtained from the $\mathrm{x}, \mathrm{y}$, width, and height values of the detected ROI. Because the distance limit uses a value of $25.57 \mathrm{~cm}$ or 85 pixels, then a distance value that exceeds $25.57 \mathrm{~cm}$ is at a safe distance and the alarm is off while a distance value of less than $25.57 \mathrm{~cm}$ is at an unsafe distance so that the alarm is on to warn the driver.

\subsection{TRAFFIC LIGHT DETECTION}

Detected traffic lights are indicated by the appearance of a white ROI rectangle on the frame. Traffic light test data will be entered into the table. Where the data is in the form of the number of lights detected, the actual number of lights, the color of the lights, the sound, and the status.

\section{TABLE 12. TESTING ON TRAFFIC LIGHTS}

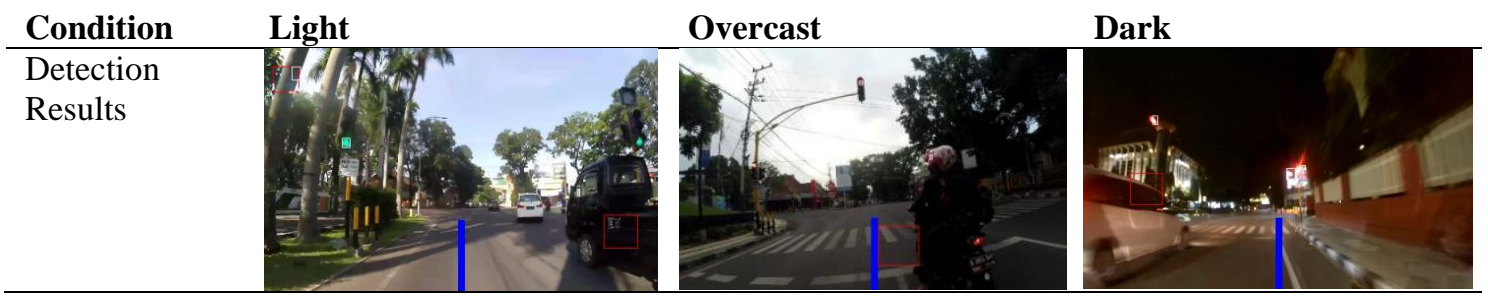

Tables 13 to 15 will show traffic light test data in light, overcast, and dark conditions. The actual number of lights is the number of traffic lights installed on the left and right of the road.

TABLE 13. TRAFFIC Light DETECTION RESULTS IN LIGHT CONDITIONS

\begin{tabular}{|c|c|c|c|c|c|}
\hline $\begin{array}{l}\text { Test } \\
\text { to }\end{array}$ & $\begin{array}{c}\text { Actual Number of } \\
\text { Lights }\end{array}$ & $\begin{array}{c}\text { Number of } \\
\text { Lights Detected }\end{array}$ & Lamp Color & Voice & Status \\
\hline 1 & 2 & 1 & Green & On & Way forward \\
\hline 2 & 2 & 1 & Green & On & Way forward \\
\hline 3 & 2 & Not Detected & - & - & - \\
\hline
\end{tabular}




$\begin{array}{llllll}4 & 2 & 2 & \text { Green } & \text { On } & \text { Way forward } \\ 5 & 2 & 2 & \text { Green } & \text { On } & \text { Way forward }\end{array}$

From Table 13 it can be seen that the third test was not detected, because the distance between the traffic light and the camera was too far and was covered by signs. Accuracy results in light or bright conditions reach $60 \%$.

TABLE 14. TRAFFIC LIGHT DETECTION RESULTS IN OVERCAST CONDITIONS

\begin{tabular}{llllll}
\hline $\begin{array}{l}\text { Test } \\
\text { to }\end{array}$ & $\begin{array}{c}\text { Actual Number of } \\
\text { Lights }\end{array}$ & $\begin{array}{c}\text { Number of } \\
\text { Lights Detected }\end{array}$ & Lamp Color & Voice & Status \\
\hline 1 & 2 & 2 & Red & On & Stop \\
2 & 2 & 2 & Red & On & Stop \\
3 & 2 & 1 & Green & On & Way forward \\
4 & 2 & 3 & Red & On & Stop \\
5 & 2 & 1 & Red & On & Stop \\
\hline
\end{tabular}

From Table 14 it can be seen that all traffic lights can be detected. However, there is still a 3rd test error. The resulting accuracy in overcast conditions is $90 \%$.

TABLE 15. TRAFFIC LIGHT DETECTION RESULTS IN DARK CONDITIONS

\begin{tabular}{|c|c|c|c|c|c|}
\hline $\begin{array}{l}\text { Test } \\
\text { to }\end{array}$ & $\begin{array}{c}\text { Actual Number of } \\
\text { Lights }\end{array}$ & $\begin{array}{c}\text { Number of } \\
\text { Lights Detected }\end{array}$ & Lamp Color & Voice & Status \\
\hline 1 & 2 & 2 & Red & On & Stop \\
\hline 2 & 2 & - & Yellow & Off & - \\
\hline 3 & 2 & 3 & Red & On & Stop \\
\hline 4 & 2 & 2 & Green & On & Way forward \\
\hline 5 & 2 & 3 & Green & On & Way forward \\
\hline
\end{tabular}

From Table 15 it can be seen that at night conditions, traffic lights are a little difficult to detect because the light emitted by the lights is too diffuse and too bright. In the second test, it was not detected because the light emitted was yellow while the detected lights were red and green. From the results obtained, it can be seen that the level of accuracy in dark conditions is $75 \%$.

\section{CONCLUSION}

From the discussion above, it can be concluded that, the driver alarm will sound if the resulting distance is less than $25.57 \mathrm{~cm}$ or 85 pixels. If the resulting distance exceeds $25.57 \mathrm{~cm}$ then the alarm does not sound, stating that the distance between the marker and the driver is long distance.

The highest traffic light detection accuracy during cloudy/overcast conditions is $90 \%$. The cause of errors when detecting traffic lights is that many objects other than traffic lights have the same color.

The system has succeeded in issuing an output in the form of a warning alarm in accordance with the conditions of the markings and traffic lights. When the red light is detected, the alarm will warn the driver to stop temporarily, if the green light the alarm will tell the driver to continue.

\section{REFERENCES}

[1]. Aneesh, A. N., Shine, L., Pradeep, R., \& Sajith, V. "Real-time Traffic Light Detection and Recognition based on Deep RetinaNet for Self Driving Cars," 2019 2nd International Conference on Intelligent Computing, Instrumentation and Control Technologies (ICICICT), pp.1554-1557, (2019), DOI: 10.1109/ICICICT46008.2019.8993293

[2]. Badan Pusat Statistik Indonesia, "Statistik transportasi darat 2019 (Land transportation statistics 2019)," BPS-Statistics, Indonesia, No. 06140.2002, ISSN.2598-5612, pp. 28-32, (2019),

[3]. Regulation of the Minister of Transportation of the Republic of Indonesia Number PM 34 of 2014 concerning Road Markers, Chapter I, Article 1.

[4]. Law of the Republic of Indonesia Number 22 of 2009 concerning Traffic and Transportation of Road, Chapter 1, Article 1.

[5]. Niu, J., Liu, Y., Guizani, M., \& Ouyang, Z. "Deep CNN-based Real-time Traffic Light Detector for Self-driving Vehicles", IEEE Transactions on Mobile Computing, 1-1, pp.1-14, (2019), DOI:10.1109/tmc.2019.2892451.

[6]. I I Dewa Gede R S, I Made W, "Gaussian filtering method to remove noise in images," Jurnal Elektronik Ilmu Komputer Udayana, vol.10, no.1, pp. 53-56, (August 2021).

[7]. Hery Sunandar, "Perbaikan kualitas citra menggunakan metode gaussian filter," MEANS (Media Informasi Analisa dan Sistem), vol.2, no.1, pp.19-22, (Juni 2017).

[8]. Abdurrahman, Muhammad Hanif, Haryadi Amran Darwito, and Akuwan Saleh. "Face recognition system for prevention of car theft with haar cascade and local binary pattern histogram using raspberry pi," EMITTER International Journal of Engineering Technology, vol. 8, no. 2, pp. 407 425, (December 2020), DOI : 10.24003/emitter.v8i2.534. 
[9]. Darwito, Haryadi Amran. Akuwan Saleh, Indria Dwi M, "Implementasi deteksi gerak berbasis image processing untuk monitoring rumah,” Seminar Nasional Teknologi Elektro Terapan (SNTET), Malang, Indonesia, vol.03, ISSN: 2581-0049, pp. 55-60,(2019).

[10]. Ding, L., Zhang, H., Xiao, J., et al,“A comprehensive approach for road marking detection and recognition”,. Multimedia Tools and Applications, (2020), DOI:10.1007/s11042-019-08384-5

[11]. Tai Huu-Phuong Tran, Cuong Cao Pham, et al, "Real-time traffic light detection using color density," in Proc. 2016 IEEE International Conference on Consumer Electronics-Asia (ICCE-Asia), Suwon, Korea, (2016), DOI:10.1109/ICCEAsia.2016.7804791.

[12]. Tao Wu and Ananth R, "A practical system for road marking detection and recognition," in Proc. 2012 Intelligent Vehicles Symposium, Alcalá de Henares, Spain, pp. 25-30, (June 3-7, 2012), DOI:10.1109/ivs.2012.6232144.

Akuwan Saleh, et. al. "Vehicle Driver Warning Systems Using Road Marking And Traffic Light Detection."American Journal of Engineering Research (AJER), vol. 11(01), 2022, pp. 185-193. 